\title{
EFFECT OF ECOLOGICAL CONDITIONS CREATED BY OVER- IRRIGATION AND LIMITED IRRIGATION ON THE ANATOMY OF MAIZE
}

\author{
TUYLU, G. İ. \\ Department of Agricultural Structures and Irrigation, Faculty of Agriculture, University of \\ Harran, Şanliurfa, Turkey \\ (e-mail: gokhantuylu@harran.edu.tr) \\ (Received $18^{\text {th }}$ Jul 2018; accepted $15^{\text {th }}$ Oct 2018)
}

\begin{abstract}
In the study carried out in Turkey in 2015, maize (Zea mays L. indentata), was cultivated by applying the drip irrigation system, with the aim of examining the effect of different irrigation applications on some anatomical features of the plant in detail. A period of 6 days was selected for irrigation interval and $\mathrm{C}_{2} \mathrm{~S}_{1}$ quality irrigation water was used. Optimum condition (100\%) and ecological conditions identified as $\pm 25 \%$ of the condition were created based on the Class A Pan method. For anatomical examination, the samples of maize were put in epon 812 and semithin sections were stained with toluidin blue. The semithin sections were examined with light microscopy and photographed. Ultrathins were examined with transmission electron microscopy (TEM) after staining with uranyl acetate and lead citrate, and their micrographs were taken. The vascular bundles surrounded the pith like a ring in the root. Very few stomata were observed in the stem. The pith was paranchymatic. The leaf was unifacial. The lower and the upper epidermis were amphistomatic and contained graminea stomate type. Numerous bullate cells with different sizes were observed in the epidermis. The mesophyll was formed by irregular cells due to stress under over-irrigation and limited irrigation conditions. The small vascular bundles were embedded in the mesophyll. The results were compared for two different ecological conditions by performing biometric measurements in some tissues in the root, stem and leaf. As a result, it was determined that maize cultivated under over-irrigation and limited irrigation conditions showed anatomical changes due to stress effect, adapted to the conditions and did not show abnormal structures compared to maize cultivated under optimum condition. Ecological condition created by reducing irrigation water by $25 \%$ in the cultivation of maize studied is anatomically convenient. The results obtained are significant for water saving in irrigation. However; morphological, physiological, etc. parameters of the plant should also be considered for an accurate suggestion.
\end{abstract}

Keywords: plant histology, plant cytology, drip irrigation, stress effect, water

\section{Introduction}

Irrigation is one of the most important factors of plant production. Water, as an abiotic ecological factor to create ecological conditions, is effective in the development of plant organs. The fact that more or less irrigation water is applied than the plant needs causes morphological and anatomical changes in some tissues of root, stem and leaf. The plant adapts to its ecological condition as a result of the changes identified as stress effect. Plants undergo changes in terms of quality of stress factor and genetical and ontogenetic features of plants. Thus, plants adapt to factors of their environment by developing stress reactions (Korkmaz and Durmaz, 2017). In this case, not only morphological reactions of plants but also their physiological and anatomical reactions, etc., should be considered as a whole.

Use of drip irrigation systems has become common, depending on technological developments in the world and in Turkey. Drip irrigation is one of the systems, which applies irrigation under control and can irrigate plant with water as needed in contrast to applying too much or too little irrigation. It has been effective where there is a shortage 
of water resource. Drip irrigation systems have been commonly used in conditions in which water resources are particularly limited in Turkey. The fact that there is a shortage of irrigation water in Mazıdağı, Mardin, requires the use of pressurized irrigation methods such as drip or sprinkler irrigation systems. Zea mays L. indentata, which is one of the plant patterns belonging to the province, has been cultivated using drip irrigation system commonly.

Maize is an important grain in the second place with respect to production and in the third place after wheat and paddy rice in terms of cultivation area. Maize is the grain having the highest yield of all and is cultivated in both cool and hot climate conditions. It is cultivated in $1848009690 \mathrm{da}, 1037791518$ ton is produced and mean yield is $561.6 \mathrm{~kg} \mathrm{da}^{-1}$ in the world. Economic value and fields of use of maize, which is an important plant in Turkey, are increasing. The cultivation area of grain maize is 6800 $192 \mathrm{da}$, the production is 6400000 ton, and the yield is $942 \mathrm{~kg} \mathrm{da}^{-1}$ in Turkey (Öktem et al., 2017). The cultivation area of maize, cultivated as the second crop in Mardin province in 2015, is $580200 \mathrm{da}$, the production is 670000 ton, and the yield is $1154 \mathrm{~kg} \mathrm{da}^{-1}$ (Anonymous, 2018).

The study aimed to anatomically examine the root, stem and leaf of maize to histologically and cytologically specify their adaptation to over-irrigation and limited irrigation conditions. In this way, supporting morphological results by examining structures of cell, tissue and organ will assist the producers and researchers to comment on the effect of different amount of irrigation water on plant development more efficiently.

\section{Materials and methods}

Mazıdağ 1 is located at 1030-1090 m above sea level, $47 \mathrm{~km}$ northwest of Mardin province in the South Eastern Anatolia Region, Turkey. Features of terrestrial climate are efficient in the province. It is hot and dry in summers but cold and rainy in winters. The average rainfall has been $667.4 \mathrm{~mm}$ and July has been the hottest month for years (Anonymous, 2017). Some climatic data belonging to cultivation area and period (July 15 - November 15) is presented in Table 1. The soil in Mazıdağı is medium-textured and contains sand, silt and clay (Table 2).

Offspring F1 included in the group of Ventoruli Italian hybrid FAO 600 (the 120day) of Zea mays L. indentata selected as research material is economical and cultivated as the second crop in Mazidağı. The time of seed planting is July 15 on average. In the study area, the irrigated parcels were arranged in completely randomized experimental design and each irrigation treatment was replicated three times. Each parcel was 5 sequenced and had 12 plants $\mathrm{m}^{-2}$. There were 13 plants in each sequence and two sequences were separated as border effect in the evaluation (Fig. 1). Irrigation water was applied by drip irrigation systems. Irrigation interval was selected as 6 days concerning application of farmers in the province. $\mathrm{C}_{2} \mathrm{~S}_{1}$ class underground water was used as irrigation water.

Conditions were designed according to Class A Pan method (Demirok and Tuylu, 2017; Demirok, 2017; Orhangazi, 2017). Class A Pan Coefficient (kcp) was obtained from the different irrigation applications in the preliminary tests $(\mathrm{kcp}=1)$. Optimum condition $\left(\mathrm{I}_{100}\right)$ was the issue of irrigation which the amount of irrigation water was as much as the amount of water evaporated from Class A Pan. The plants cultivated under optimum condition were defined as control group in the study. 
While over-irrigation condition $\left(\mathrm{I}_{125}\right)$ was created by increasing the amount of optimum irrigation water by $25 \%$, limited irrigation condition $\left(I_{75}\right)$ was created by reducing the amount of optimum irrigation water by $25 \%$. In the study, base fertilizer, $\mathrm{N}$ and $\mathrm{P}_{2} \mathrm{O}_{5}$ were evenly applied to the parcels for each condition $\left(5 \mathrm{~kg} \mathrm{da}^{-1}\right)$. Fighting against diseases was not required and the weeds were cleared by hand.

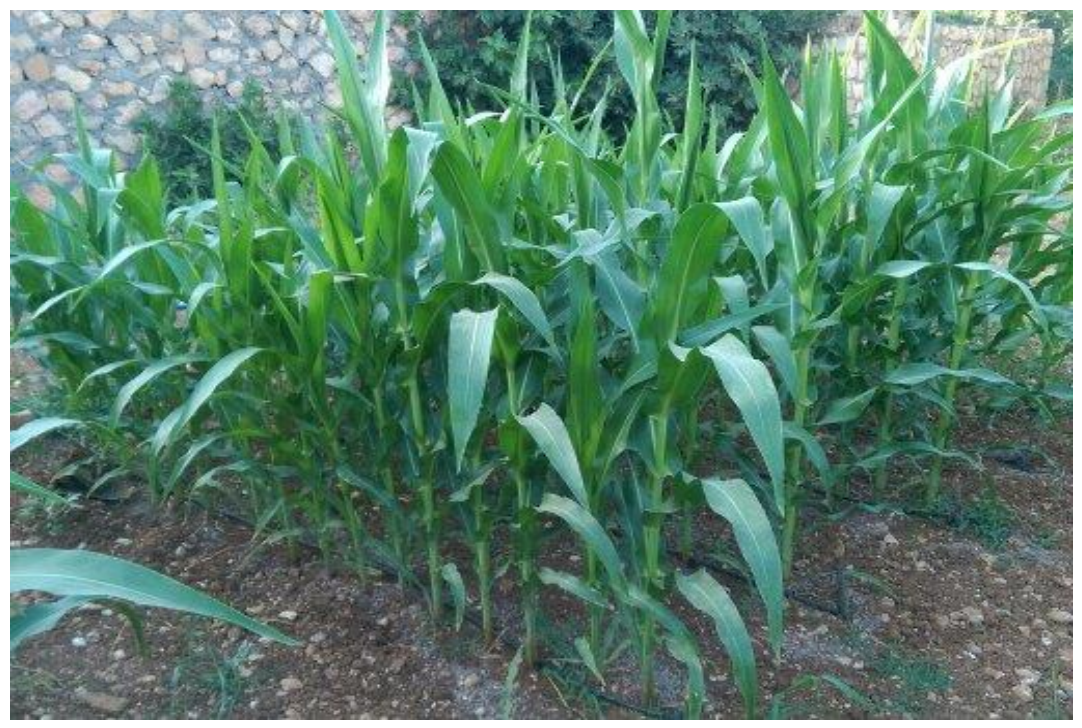

Figure 1. Zea mays L. indentata

Table 1. Some climatic data of the study area in 2015 (Anonymous, 2017)

\begin{tabular}{|c|c|c|c|c|c|c|c|c|}
\hline \multicolumn{2}{|c|}{ Climatic data } & \multirow{2}{*}{$\begin{array}{c}\text { Maximum } \\
\text { temperature } \\
\left({ }^{\circ} \mathrm{C}\right)\end{array}$} & \multirow{2}{*}{\begin{tabular}{|c|} 
Minimum \\
temperature \\
$\left({ }^{\circ} \mathrm{C}\right)$
\end{tabular}} & \multirow{2}{*}{$\begin{array}{l}\text { Evaporation } \\
\text { (mm) }\end{array}$} & \multirow{2}{*}{$\begin{array}{c}\text { Relative } \\
\text { moisture } \\
(\%)\end{array}$} & \multirow{2}{*}{\begin{tabular}{|c|} 
Wind \\
speed (m \\
$\left.\operatorname{sn}^{1}\right)$ \\
\end{tabular}} & \multirow{2}{*}{$\begin{array}{c}\text { Sunshine } \\
\text { (hours) }\end{array}$} & \multirow{2}{*}{$\begin{array}{c}\text { Rainfall } \\
(\mathbf{m m})\end{array}$} \\
\hline Months & Decades & & & & & & & \\
\hline \multirow{3}{*}{ June } & 1 & 30.4 & 16.5 & 22.5 & 32.8 & 1.9 & 10.6 & 2.0 \\
\hline & 2 & 31.4 & 16.5 & 23.8 & 33.2 & 1.9 & 13.0 & 0.0 \\
\hline & 3 & 32.6 & 17.8 & 27.8 & 32.0 & 1.9 & 12.5 & 0.0 \\
\hline \multirow{3}{*}{ July } & 1 & 37.0 & 20.5 & 17.3 & 23.9 & 1.8 & 12.4 & 0.0 \\
\hline & 2 & 38.0 & 23.5 & 8.7 & 22.7 & 2.4 & 12.0 & 0.0 \\
\hline & 3 & 38.5 & 22.9 & 14.2 & 18.0 & 1.6 & 12.0 & 0.0 \\
\hline \multirow{3}{*}{ August } & 1 & 37.8 & 22.2 & 19.2 & 24.0 & 1.8 & 11.7 & 0.0 \\
\hline & 2 & 37.0 & 21.7 & 24.5 & 29.9 & 1.8 & 12.2 & 0.0 \\
\hline & 3 & 34.2 & 20.3 & 32.3 & 27.3 & 1.8 & 11.3 & 0.0 \\
\hline \multirow{3}{*}{ September } & 1 & 35.0 & 20.3 & 19.3 & 24.4 & 1.5 & 9.8 & 0.0 \\
\hline & 2 & 34.6 & 20.1 & 27.2 & 21.0 & 1.4 & 10.1 & 0.0 \\
\hline & 3 & 30.6 & 17.2 & 26.7 & 33.1 & 1.6 & 10.8 & 0.0 \\
\hline \multirow{3}{*}{ October } & 1 & 25.2 & 13.6 & 28.4 & 56.4 & 1.4 & 7.9 & 11.4 \\
\hline & 2 & 25.2 & 12.0 & 33.0 & 45.8 & 1.2 & 9.5 & 0.3 \\
\hline & 3 & 19.3 & 11.1 & 25.7 & 84.9 & 1.1 & 4.2 & 63.6 \\
\hline \multirow{3}{*}{ November } & 1 & 16.3 & 5.8 & 24.4 & 67.2 & 1.1 & 6.9 & 13.8 \\
\hline & 2 & 14.0 & 4.9 & 21.7 & 59.6 & 1.4 & 7.4 & 22.8 \\
\hline & 3 & 14.7 & 3.6 & 26.5 & 64.2 & 1.0 & 6.2 & 0.7 \\
\hline Year & 2015 & 21.2 & 9.7 & 821.1 & 55.9 & 1.6 & 94.3 & 431.9 \\
\hline
\end{tabular}


Table 2. Soil properties of the study area

\begin{tabular}{|c|c|c|c|c|c|c|c|c|}
\hline \multirow[b]{2}{*}{$\begin{array}{l}\text { Soil depth } \\
\text { (cm) }\end{array}$} & \multirow[b]{2}{*}{$\begin{array}{l}\text { Field capasity } \\
\qquad(\%)\end{array}$} & \multirow{2}{*}{$\begin{array}{c}\text { Wilting point } \\
(\%)\end{array}$} & \multirow[b]{2}{*}{$\begin{array}{c}\text { Bulk density } \\
\left(\mathrm{g} \mathrm{cm}^{-3}\right)\end{array}$} & \multirow[b]{2}{*}{$\begin{array}{c}\text { Infiltration } \\
\left(\mathrm{mm} \mathrm{h}^{-1}\right)\end{array}$} & \multirow[b]{2}{*}{ pH } & \multicolumn{3}{|c|}{ Texture } \\
\hline & & & & & & $\begin{array}{c}\text { Sand } \\
(\%)\end{array}$ & $\begin{array}{l}\text { Silty } \\
(\%)\end{array}$ & $\begin{array}{l}\text { Clay } \\
(\%)\end{array}$ \\
\hline $0-90$ & 36.2 & 18.5 & 1.285 & 3.3 & 7.6 & 34.4 & 30.6 & 35.0 \\
\hline
\end{tabular}

For anatomical studies, samples of root, stem and leaf were protected in ethanol $(70 \%)$. The tiny pieces of the samples which were taken from lower, middle and upper parts of the roots, stems and leaves were fixed at $+4{ }^{\circ} \mathrm{C}$ by using $3 \%$ gluter aldehyde (with $0.1 \mathrm{M}$ Na-P buffer solution) and $1 \%$ osmium tetroksit (with $0.1 \mathrm{M} \mathrm{Na-P}$ buffer solution), respectively. After dehidration and saturation, the samples were embedded in epoxy resin (Luft, 1961; Tuylu, 2015). The blocks were kept in an incubator at $30^{\circ} \mathrm{C}$ for 1 night, at $45^{\circ} \mathrm{C}$ for 1 day and at $60{ }^{\circ} \mathrm{C}$ for 1 night to be polymerized. Semithins and ultrathins were taken in cross-section from the blocks trimmed with ultra microtome (Reichert OMU-4). The thickness of semithins was $0.5-1 \mu \mathrm{m}$ and the thickness of ultrathins was 60-100 nm. The semithins prepared were stained with toluidin blue and they were examined with light microscope (Leica 1000). The results were photographed with digital camera (Leica EC3), and biometric measurements were performed in some tissues with Las v4.3 program. In the anatomical study, the total number of crosssections taken from the plants and examined was 90 on 9 preparats for 3 plants in each replication and a total of 270 values of measurement were obtained by taking 3 from each section. The arithmetic mean of the values of measurements and mean standard error were calculated by using basic statistical methods in Excel spreadsheet, and the results were anatomically expressed. On the other hand, after the ultrathins were stained with uranyl acetate and lead citrate (Stempak and Ward, 1964; Tuylu, 2015), they were examined with transmission electron microscopy (TEM) (JEOL CX-100) and micrographed. The total number of ultrathins examined in each replication was 27 in 9 grid for cytological evaluations.

\section{Results}

\section{Roots}

The vascular bundles surrounded the pith like a ring in the roots cultivated under each of the three conditions. Air spaces in the cortex under $\mathrm{I}_{125}$ and $\mathrm{I}_{75}$ conditions were more than the ones under $\mathrm{I}_{100}$ condition (Figs. $2 A, 3 A, 3 B$, and 4A, 4B). The bundle was surrounded by one layered pericycle and one layered endodermis under $\mathrm{I}_{100}$ (Figure $2 B$ ). The endodermis was 1-2 layered and the pericycle was one layered under $\mathrm{I}_{125}$ (Figure $3 A$ and $3 B$ ). One layered large-celled endodermis and one layered pericycle formed by some degradation were observed under $\mathrm{I}_{75}$ (Figure $4 A$ and $4 B$ ). Starch grains were clearly observed under each of the three conditions (Figure 2D, 3D and $4 F$ ). Lipid distribution observed in the root cultivated under optimum condition was dense (Fig. 2C). Lipids were rarely observed in the roots under $\mathrm{I}_{125}$ and $\mathrm{I}_{75}$. When the roots were cytologically examined, it can be expressed that lipid molecules are more electron-dense than starch molecules under $\mathrm{I}_{100}$ (Fig. 2C, 2D). The cortex formed by thin-walled paranchyma cells and thin-walled xylem vessels were observed under $\mathrm{I}_{100}$. Electron density was also low in these cells (Fig. 3C, 3D). While electron density was low in some paranchyma and xylem 
cells under $\mathrm{I}_{125}$ (Fig. 3C, 3D, 3E), the ones under $\mathrm{I}_{75}$ were more electron-dense than the others (Fig. 4C, 4D, 4E). The wall thickness of paranchyma and xylem cells under $\mathrm{I}_{125}$ and $\mathrm{I}_{75}$ was relatively thicker than the ones under $\mathrm{I}_{100}$.
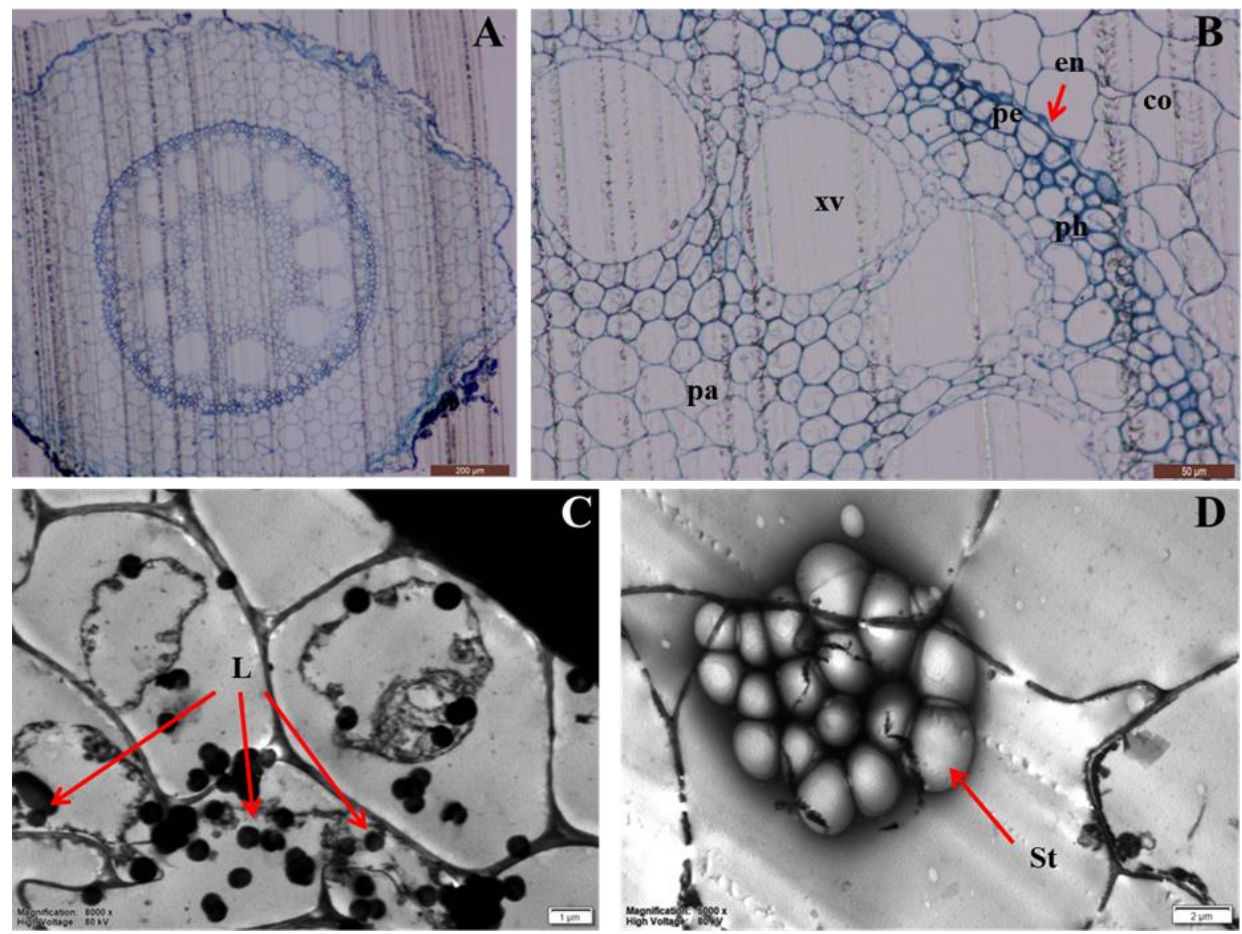

Figure 2. Histological and cytological structure of root in Zea mays L. indentata under $I_{100}$ condition (cross-section). A. general shape of root, bar $=200 \mu \mathrm{m}$, B. cortex (co)ndodermis (en), pericycle (pe), phloem (ph), xylem vessel (xv), paranchyma (pa)ar $=50 \mu \mathrm{m}$, C. lipid (L), bar $=$ $1 \mu \mathrm{m}$ (micrograph), D. starch (St), bar $=2 \mu \mathrm{m}$ (micrograph)

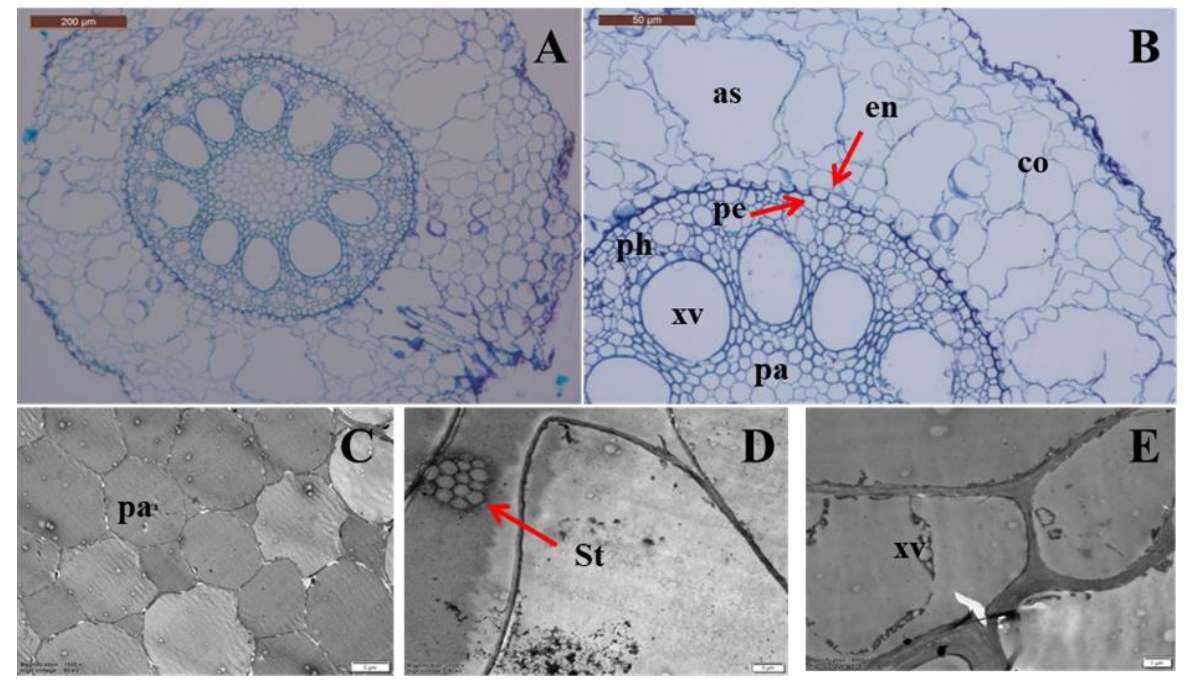

Figure 3. Histological and cytological structure of root in Zea mays L. indentata under $I_{125}$ condition (cross-section). A. general shape of root, bar $=200 \mu \mathrm{m}$, B. cortex (co), air space (as), endodermis (en), pericycle (pe), phloem (ph), xylem vessel ( $x v)$, paranchyma (pa), bar $=50 \mu \mathrm{m}$,

C. paranchyma (pa), bar $=5 \mu \mathrm{m}$ (micrograph), D. starch (St), bar $=5 \mu \mathrm{m}$ (micrograph), E.

xylem vessel (xv), bar $=1 \mu \mathrm{m}$ (micrograph) 

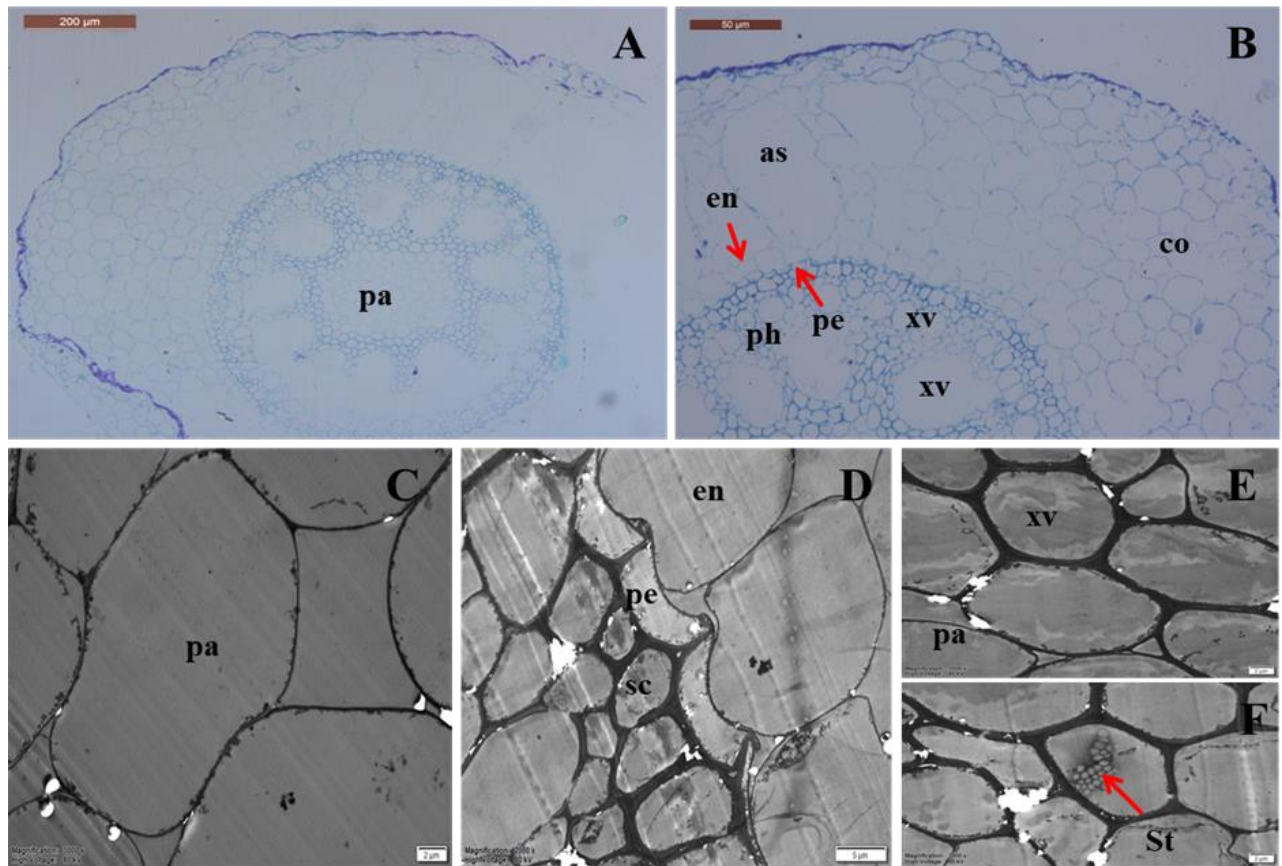

Figure 4. Histological and cytological structure of root in Zea mays L. indentata under $I_{75}$ condition (cross-section). A. general shape of root, paranchyma (pa), bar $=200 \mu \mathrm{m}, \mathrm{B}$. cortex (co), air space (as), endodermis (en), pericycle (pe), phloem (ph), xylem vessel (xv), bar = $50 \mu \mathrm{m}, \mathrm{C}$. paranchyma (pa), bar $=2 \mu \mathrm{m}$ (micrograph), D. endodermis (en), pericycle (pe), sclerenchyma (sc), bar $=5 \mu \mathrm{m}$ (micrograph), E. xylem vessel (xv), paranchyma (pa), bar = $2 \mu m$ (micrograph), F. starch (St), bar $=2 \mu m$ (micrograph)

Biometric measurements were performed in some tissues in the roots. According to the results, it was determined that the thickness of cortex increased $(p<0.05)$ when the plant was irrigated with more or less water than its optimum water need. As long as the amount of the irrigation water applied reduced, it was observed that the diameter of xylem vessel narrowed ( $\mathrm{p}<0.01)$ (Fig. 5).
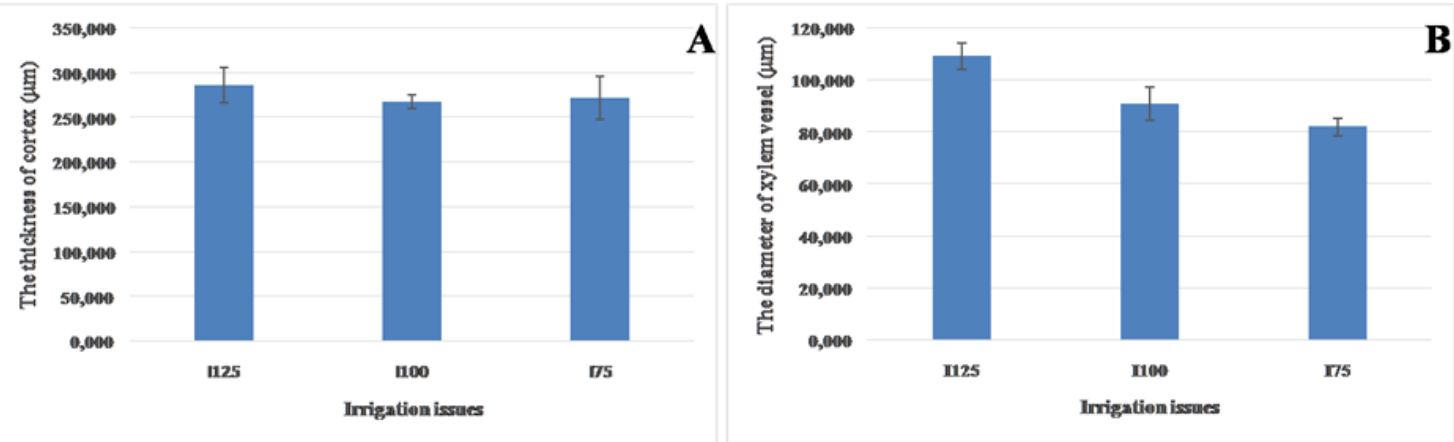

Figure 5. The relationship between the amount of irrigation water and measurements of some tissues in roots of Zea mays $L$. indentata under different irrigation conditions. A. The relationship between the amount of irrigation water and the thickness of cortex, $B$. The relationship between the amount of irrigation water and the diameter of xylem vessel. $p<0.01$ : highly significant, $p<0.05$ : significant, $p>0.05$ : no significant 


\section{Stems}

The stems cultivated under each of the three irrigation systems were surrounded by one layered epidermis. Stomate was rarely observed (Figs. 6A, 6B, 7A, and $8 A, 8 B$ ).

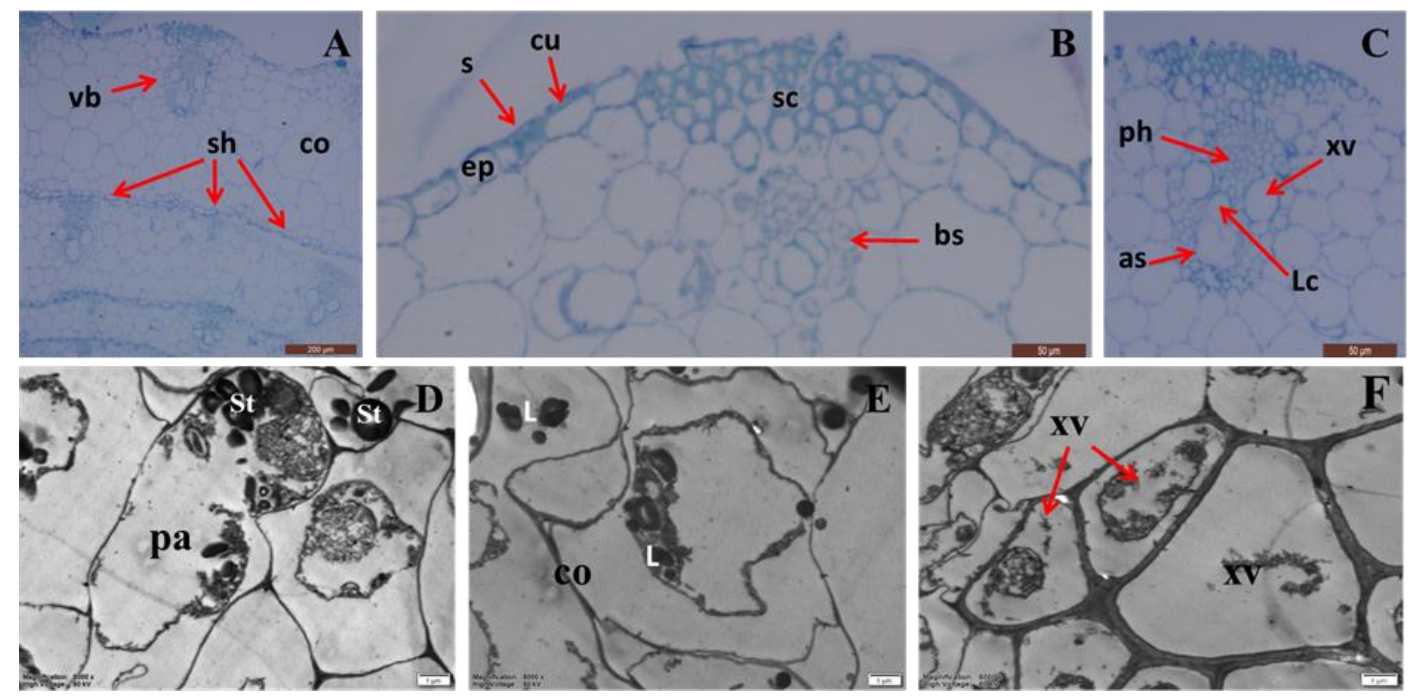

Figure 6. Histological and cytological structure of stem in Zea mays L. indentata under I ${ }_{100}$ condition (cross-section). A. vascular bundle (vb), starch sheath (sh), cortex (co), bar = $200 \mu \mathrm{m}$, B. cuticle (cu), stomate (s), epidermis (ep), sclerenchyma (sc), bundle sheath (bs), bar

$=50 \mu \mathrm{m}, C$. phloem (ph), xylem vessel (xy), lacuna (Lc), air space (as), bar $=50 \mu \mathrm{m}, D$. paranchyma (pa), starch (St), bar $=1 \mu \mathrm{m}$ (micrograph), E. cortex (co), lipid (L), bar $=1 \mu \mathrm{m}$ (micrograph), F. xylem vessel (xy), bar $=1 \mu \mathrm{m}$ (micrograph)

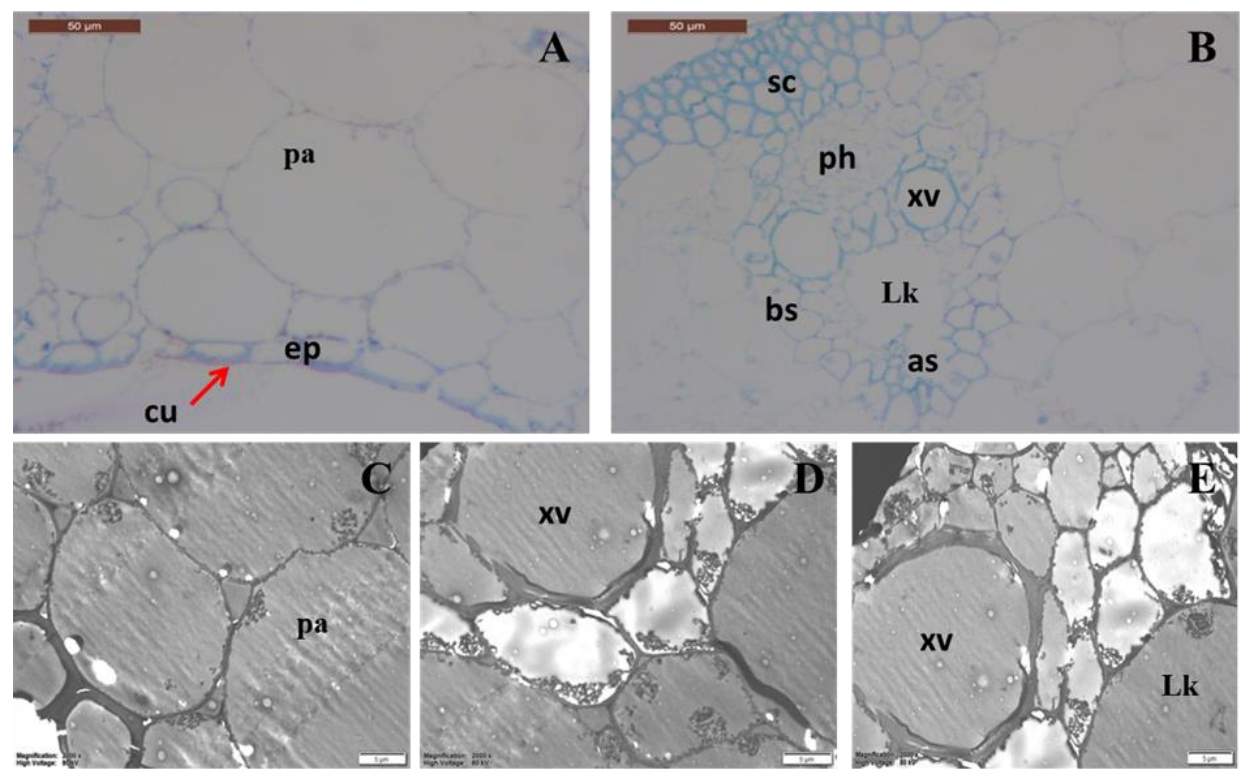

Figure 7. Histological and cytological structure of stem in Zea mays L. indentata under $I_{125}$ condition (cross-section). A. cuticle (cu), epidermis (ep), paranchyma (pa), bar =50 $\mu \mathrm{m}, \mathrm{B}$. sclerenchyma (sc), bundle sheath (bs), phloem (ph), xylem vessel (xy), lacuna (Lc), air space (as), bar $=50 \mu \mathrm{m}$, C. paranchyma (pa), bar $=5 \mu \mathrm{m}$ (micrograph), D. xylem vessel (xy), bar $=$ $5 \mu \mathrm{m}$ (micrograph), E. xylem vessel (xy), lacuna (Lc), bar $=5 \mu \mathrm{m}$ (micrograph) 

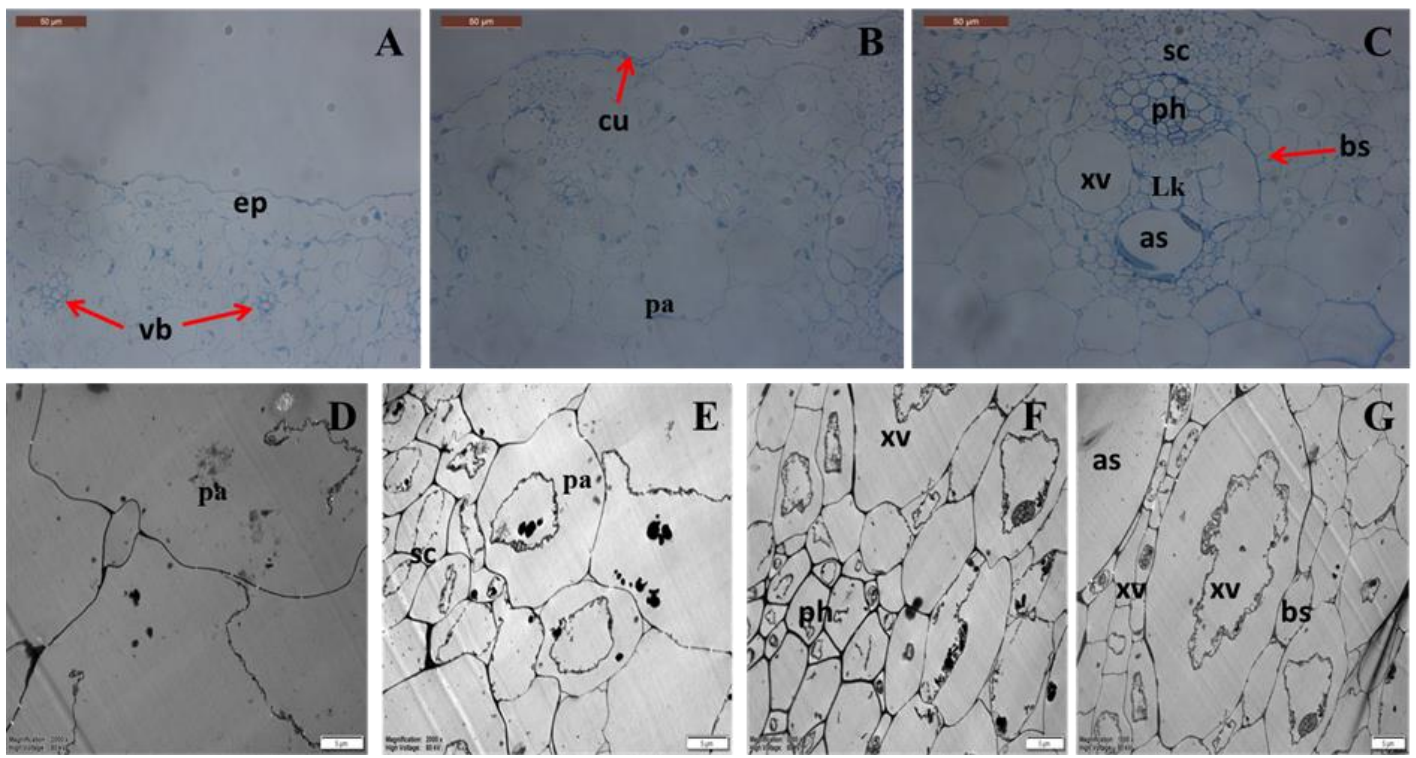

Figure 8. Histological and cytological structure of stem in Zea mays L. indentata under $I_{75}$ condition (cross-section). A. epidermis (ep), vascular bundle (vb), bar $=50 \mu \mathrm{m}, \mathrm{B}$. cuticle (cu), paranchyma (pa), bar $=50 \mu \mathrm{m}, \mathrm{C}$. sclerenchyma (sc), bundle sheath (bs), phloem (ph), xylem vessel (xy), lacuna (Lc), air space (as), bar $=50 \mu \mathrm{m}, \mathrm{D}$ and E. paranchyma (pa), bar $=5 \mu \mathrm{m}$ (micrograph), F. phloem (ph), xylem vessel (xy), bar $=5 \mu \mathrm{m}$ (micrograph), G. bundle sheath (bs), xylem vessel (xy), air space (as), bar $=5 \mu \mathrm{m}$ (micrograph)
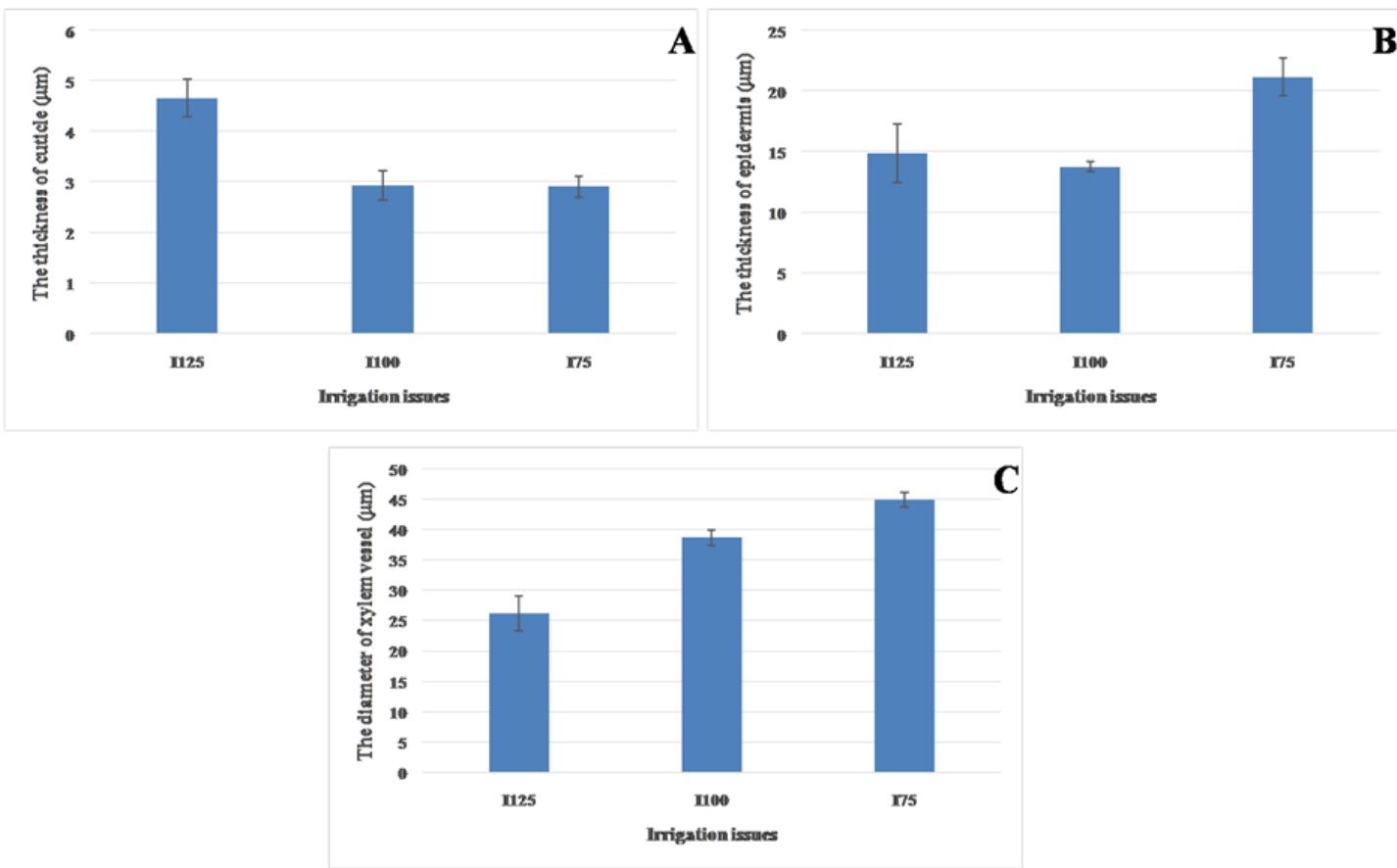

Figure 9. The relationship between the amount of irrigation water and measurements of some tissues in stems of Zea mays L. indentata under different irrigation conditions. A. the relationship between the amount of irrigation water and the thickness of cuticle, $B$. the relationship between the amount of irrigation water and the thickness of epidermis, $C$. the relationship between the amount of irrigation water and the diameter of xylem vessel. $p<0.01$ : highly significant, $p<0.05$ : significant, $p>0.05$ : no significant 
The vascular bundles formed by xylem, phloem, lacuna and air spaces were generally surrounded by the bundle sheath. Irregularity was observed in the bundle sheath cells around small- and big-celled vascular bundles under $\mathrm{I}_{75}$ (Fig. 8C, 8G). The xylem and the phloem were supported by a few layered sclerenchyma tissue (Figs. 6A, 6B, 6C, 7B and $8 A, 8 C)$. The pith was paranchymatic. The cortex paranchyma cells were cytologically large and thin-walled (Figs. $6 D, 6 E, 7 A, 7 C$, and $8 B, 8 D, 8 E$ ). Starch and lipid molecules were generally observed in paranchyma cells in the stem under $\mathrm{I}_{100}$. Starch molecules were more electron-dense than lipid molecules (Fig. 6D, 6E). Starch and lipid were rarely observed under $\mathrm{I}_{125}$ and $\mathrm{I}_{75}$. Low electron density was observed under the three conditions (Figs. $6 F, 7 D, 7 E$, and $8 F, 8 G$ ).

Biometric measurements were performed in some tissues in the stems. According to the results, it was figured out that $\mathrm{I}_{125}$ application increased the thickness of cuticle $(\mathrm{p}<0.01)$ while $\mathrm{I}_{75}$ application did not affect it clearly $(\mathrm{p}>0.05)$. It was observed that the thickness of epidermis $\left(\mathrm{p}>0.05\right.$ ) was not clearly affected under $\mathrm{I}_{125}$ while it increased highly significantly under $\mathrm{I}_{75}(\mathrm{p}<0.01)$. The diameter of xylem vessel ( $\mathrm{p}<0.01)$ increased highly significantly as long as irrigation water reduced (Fig. 9).

\section{Leaves}

The leaves cultivated under the three irrigation conditions were unifacial and amphistomatic, and stomate was in graminea type. Numerous and differently-sized bullate cells were seen in the epidermis. The bundle sheath surrounded the big vascular bundle in the midrib region and the sclerenchyma supported it on both sides. The small vascular bundles were embedded in the mesophyll (Figs. 10A, 10B, 10C, 11A, 11B,11C, $11 \mathrm{D}, 11 \mathrm{E}$, and $12 \mathrm{~A}, 12 \mathrm{~B}, 12 \mathrm{C}$ ). Average number of stomate in the upper and the lower epidermis under $\mathrm{I}_{125}$ and $\mathrm{I}_{75}$ condition distinctly reduced due to stress effect. The leaf responded to over-irrigation and limited irrigation similarly with regard to the average number of stomate.

It was observed that cytologically mesophyll cells were oval or round and regular under $\mathrm{I}_{100}$ (Fig. 10D, 10E) while the ones under $\mathrm{I}_{125}$ and $\mathrm{I}_{75}$ were more irregular (Figs. 11A, 11G and 12A, 12C). Electron density in the vascular bundles and in bundle sheath cells around them under $\mathrm{I}_{75}$ was more than in the bundles under $\mathrm{I}_{100}$ and $\mathrm{I}_{125}$ (Figs. 10F, 11G, 11H, and 12D, 12E, 12F). Starch and lipid molecules were observed in the leaves under $\mathrm{I}_{125}$ and $\mathrm{I}_{75}$ (Fig. $11 F$ ). On the other hand, starch and lipid molecules were more often seen in the bundle sheath cells under I $_{75}$. Lipids were more electrondense than starch (Fig. 12E). Starch and lipid molecules in the leaves under $\mathrm{I}_{100}$ were seldom observed.

Biometric measurements were performed in some tissues in the leaves. According to the results of the measurements, under $\mathrm{I}_{125}$ and $\mathrm{I}_{75}$ conditions the thickness of cuticle highly significantly reduced $(p<0.01)$. It was figured out that the thickness of upper epidermis under $\mathrm{I}_{125}$ reduced $(\mathrm{p}<0.01)$ while it increased $(\mathrm{p}<0.01)$ under $\mathrm{I}_{75}$. The thickness of lower epidermis under $\mathrm{I}_{125}$ was not significantly affected $(\mathrm{p}>0.05)$ while it distinctly increased $(\mathrm{p}<0.01)$ under $\mathrm{I}_{75}$. The number of stomate in the upper and the lower epidermis under $\mathrm{I}_{125}$ and $\mathrm{I}_{75}$ conditions reduced prominently $(\mathrm{p}<0.01)$. As long as the amount of irrigation water reduced, the width and the length of bullate cell increased clearly $(\mathrm{p}<0.01)$. While the width of mesophyll under $\mathrm{I}_{125}$ distinctly increased $(\mathrm{p}<0.01)$, it slightly increased $(\mathrm{p}<0.05)$ under $\mathrm{I}_{75}$. The diameter of xylem vessel under $\mathrm{I}_{125}$ narrowed $(\mathrm{p}<0.05)$, but it highly significantly narrowed $(\mathrm{p}<0.01)$ under $\mathrm{I}_{75}$. The distance of bundles under $I_{125}$ and $I_{75}$ highly distinctly increased $(p<0.01)$ and was pretty 
much affected by the over-irrigation condition. It was figured out that the thickness of midrib region was affected by over-irrigation $(\mathrm{p}<0.05)$, but it highly distinctly got thinner $(\mathrm{p}<0.01)$ under $\mathrm{I}_{75}$. While the width of big vascular bundle under $\mathrm{I}_{125}$ increased $(\mathrm{p}$ $<0.05$ ), it highly distinctly reduced ( $<$ 0.01) under $\mathrm{I}_{75}$ (Figs. 13 and 14).
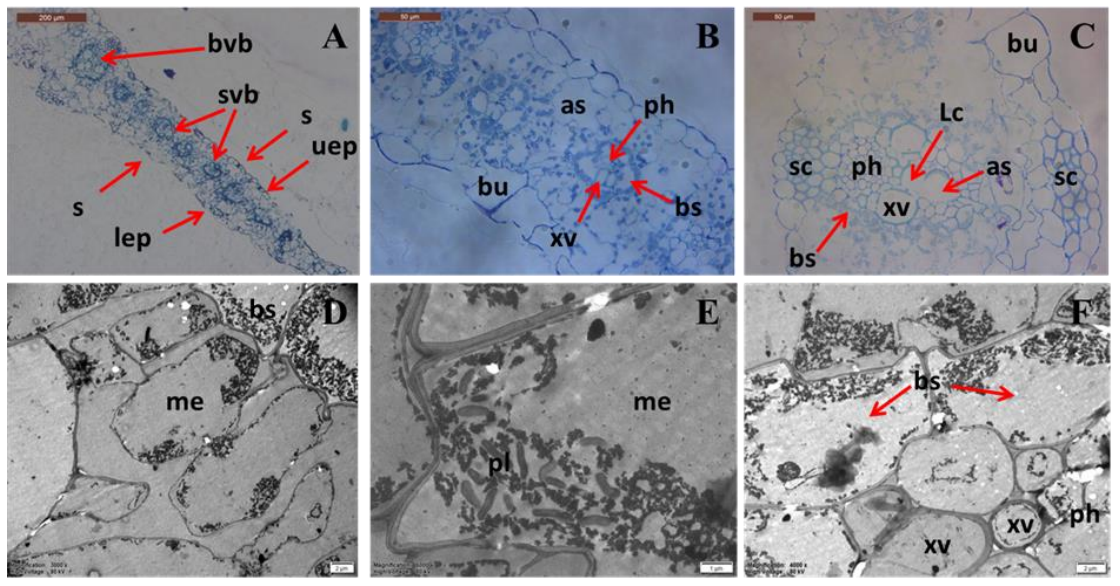

Figure 10. Histological and cytological structure of leaf in Zea mays L. indentata under $I_{100}$ condition (cross-section). A. upper epidermis, (uep), lower epidermis (lep), big vascular bundle (bvb), small vascular bundle (svb), stomate (s), bar $=200 \mu \mathrm{m}, \mathrm{B}$. bullate cell (bu), bundle sheath (bs), xylem vessel (xy), phloem (ph), air space (as), bar $=50 \mu \mathrm{m}$, C. bullate cell (bu), sclerenchyma (sc), bundle sheath (bs), xylem vessel (xy), phloem (ph), lacuna $(L c)$, air space

(as), bar $=50 \mu \mathrm{m}, D$. bundle sheath (bs), mesophyll (me), bar = $2 \mu \mathrm{m}$ (micrograph), $E$. mesophyll (me), plastids (pl), bar $=1 \mu \mathrm{m}$ (micrograph), F. bundle sheath (bs), xylem vessel (xy), phloem (ph), bar $=2 \mu \mathrm{m}$ (micrograph)
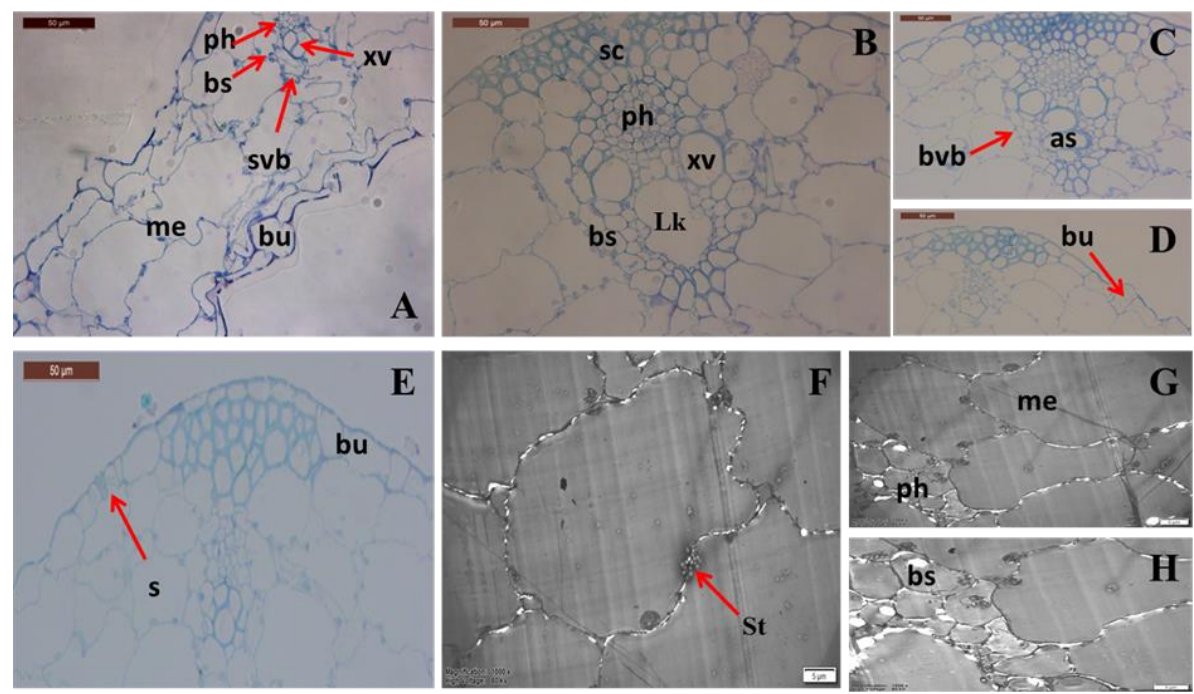

Figure 11. Histological and cytological structure of leaf in Zea mays L. indentata under $I_{125}$ condition (cross-section). A. bullate cell (bu), mesophyll (me), small vascular bundle (svb), bundle sheath (bs), xylem vessel (xy), phloem (ph), bar $=50 \mu \mathrm{m}, \mathrm{B}$. sclerenchyma (sc), bundle sheath (bs), xylem vessel (xy), phloem (ph), lacuna (Lc), bar $=50 \mu \mathrm{m}, C$. big vascular bundle (bvb), air space (as), bar $=50 \mu \mathrm{m}, \mathrm{D}$. bullate cell (bu), bar $=50 \mu \mathrm{m}$, E. stomate (s), bullate cell (bu), bar $=50 \mu \mathrm{m}$, F. starch (St), bar $=5 \mu \mathrm{m}$ (micrograph), G. mesophyll (me), phloem (ph), bar $=5 \mu \mathrm{m}$ (micrograph), H. bundle sheath (bs), bar $=5 \mu \mathrm{m}$ (micrograph) 

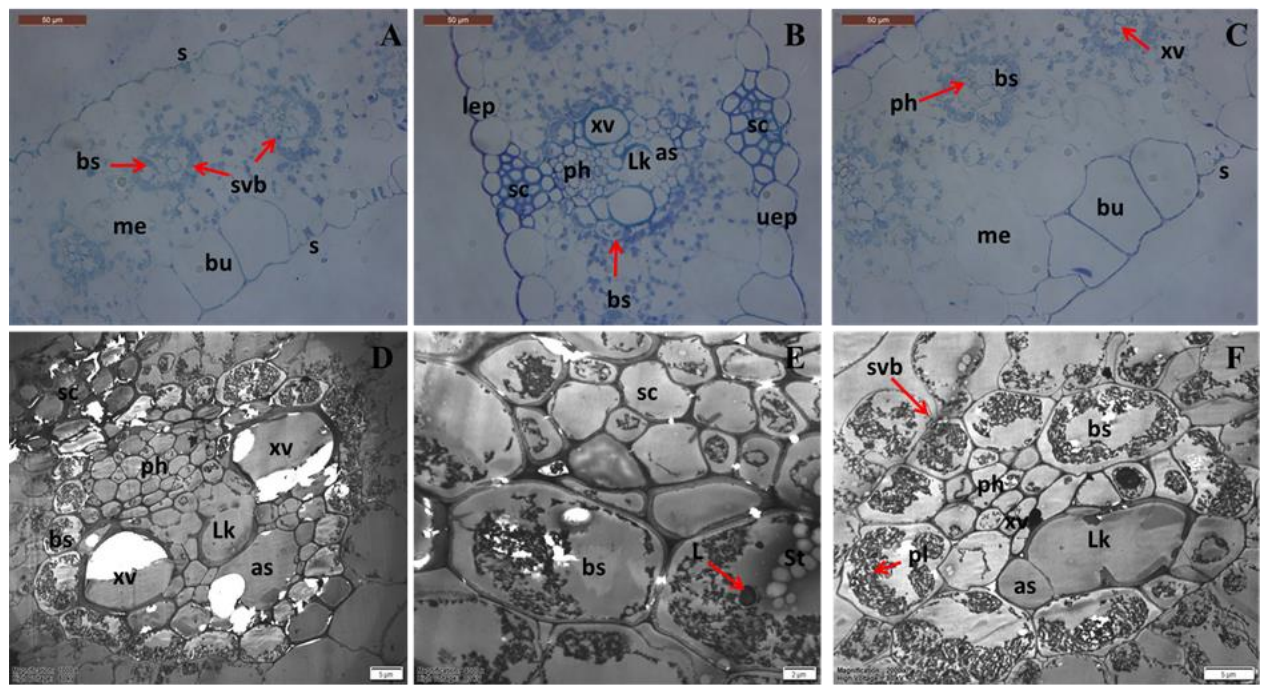

Figure 12. Histological and cytological structure of leaf in Zea mays L. indentata under $I_{75}$ condition (cross-section). A. stomate (s), bullate cell (bu), small vascular bundle (svb), bundle sheath (bs), bar $=50 \mu \mathrm{m}$, B. upper epidermis, (uep), lower epidermis (lep), big vascular bundle $(b v b)$, sclerenchyma (sc), bundle sheath (bs), xylem vessel (xy), phloem (ph), lacuna (Lc), air

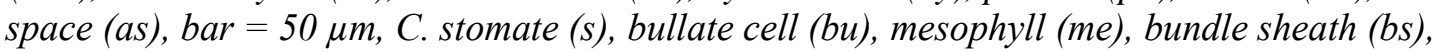
xylem vessel ( $x y$ ), phloem (ph), bar $=50 \mu \mathrm{m}$, D. sclerenchyma (sc), bundle sheath (bs), xylem vessel (xy), phloem (ph), lacuna (Lc), air space (as), bar $=5 \mu \mathrm{m}$ (micrograph), E. sclerenchyma

(sc), bundle sheath (bs), starch (St), lipid (L), bar $=2 \mu \mathrm{m}$ (micrograph), $F$. small vascular bundle (svb), bundle sheath (bs), xylem vessel (xy), phloem (ph), lacuna (Lc), air space (as), bar $=5 \mu \mathrm{m}$ (micrograph)
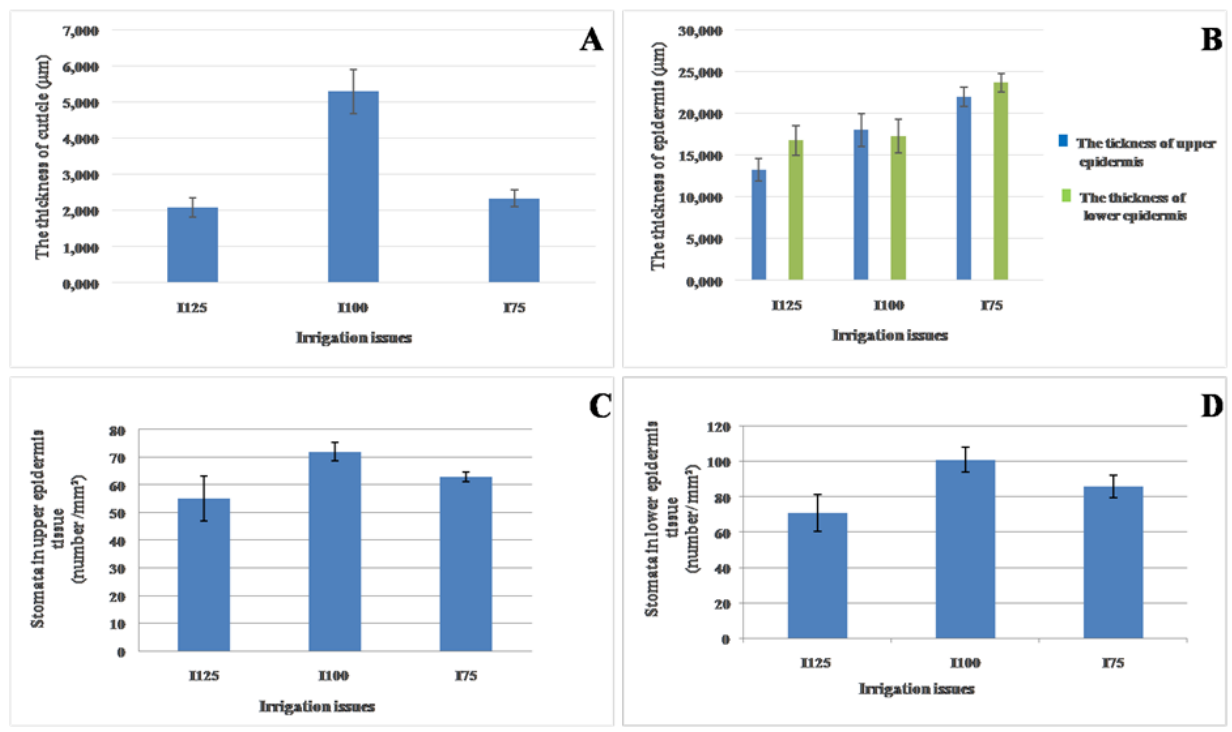

Figure 13. The relationship between the amount of irrigation water and measurements of some tissues in leaves of Zea mays L. indentata under different irrigation conditions. A. the relationship between the amount of irrigation water and the thickness of cuticle, B. the relationship between the amount of irrigation water and the thickness of epidermis, $C$. the relationship between the amount of irrigation water and the number of stomata in upper epidermis tissue, D. the relationship between the amount of irrigation water and the number of stomata in lower epidermis tissue. $p<0.01$ : highly significant, $p<0.05$ : significant, $p>0.05$ : no significant 


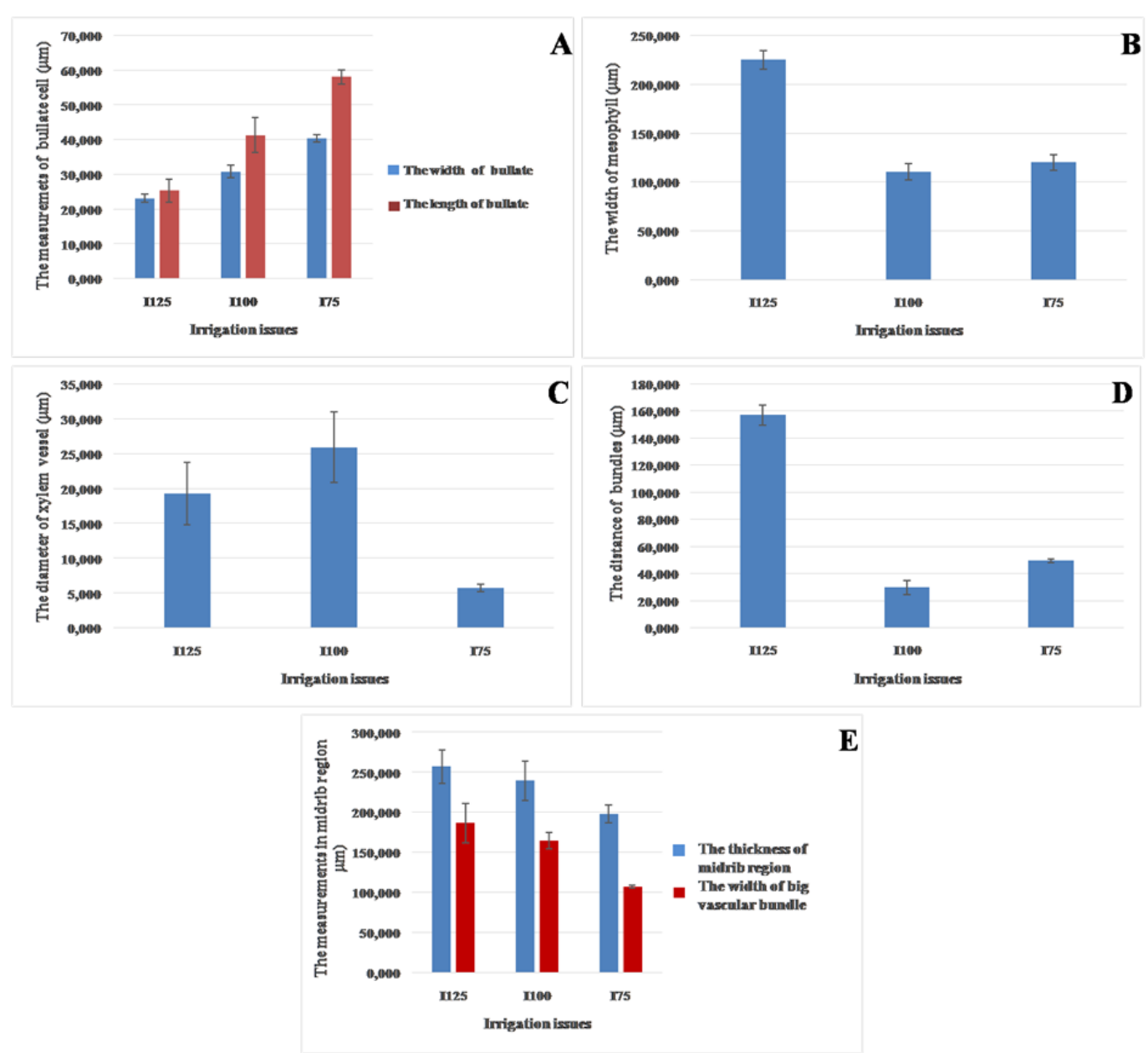

Figure 14. The relationship between the amount of irrigation water and measurements of other tissues in leaves of Zea mays $L$. indentata under different irrigation conditions. A. the relationship between the amount of irrigation water and the measurements of bullate cell, $B$. the relationship between the amount of irrigation water and the width of mesophyll, $C$. the relationship between the amount of irrigation water and the diameter of xylem vessel, $D$. the relationship between the amount of irrigation water and the distance of bundles, $E$. the relationship between the amount of irrigation water and the measurements in midrib region. $p$ $<0.01$ : highly significant, $p<0.05$ : significant, $p>0.05$ : no significant

\section{Discussion}

Anatomical features of the root, stem and leaf of the plants cultivated under overirrigation and limited irrigation conditions did not indicate any distinct anomaly compared to plants cultivated under optimum condition. In all of the plants studied, anatomical features of root, stem and leaf were generally similar to the features mentioned in Metcalfe (1960).

When the roots were histologically and cytologically examined, air gaps in the cortex under $\mathrm{I}_{125}$ and $\mathrm{I}_{75}$ conditions were much more than the ones under $\mathrm{I}_{100}$. The thickness of the cortex under $\mathrm{I}_{125}$ and $\mathrm{I}_{75}$ conditions increased. The diameter of xylem vessel narrowed as the amount of irrigation water reduced. The fact that the diameter of xylem vessel under $\mathrm{I}_{125}$ was larger than the other ones can be defined as a response to water stress. Tuylu (2018) cultivated Ceren variety of tomato under hydroponic system and stated that 
xylem vessels were large and clear and phloems were generally smaller and less than xylem vessels under water stress. It was also stated that cortex and xylem vessels in the root were affected by water stress. It was observed that the thickness of the wall of paranchyma and xylem cells under $\mathrm{I}_{125}$ and $\mathrm{I}_{75}$ was relatively thicker than the ones under $\mathrm{I}_{100}$. Starch grains were distinctly seen under the three conditions. While distribution of lipid in the root cultivated under $\mathrm{I}_{100}$ was densely observed, lipids in the roots under $\mathrm{I}_{125}$ and $\mathrm{I}_{75}$ were rarely seen. Korkmaz and Durmaz (2017) stated that plants try to survive by developing a lot of recyclable and non-recyclable reactions against all the abiotic environmental factors perceived. Electron density in paranchyma and xylem cells under $\mathrm{I}_{100}$ was low. Electron density in paranchyma and xylem cells in some sections under $\mathrm{I}_{125}$ was low, but the ones under $\mathrm{I}_{75}$ were more electron dense. Water deficit in the environment of life causes a negative water potential in the protoplasm. Water deficit stress tolerance was observed in almost all plant species but its amount varies from one species to another (Abdul Jaleel et al., 2007). Electron density observed in the cells under I 75 can be ascribed to the fact that negative water potential increased in the cells under drought condition. That electron density in the cells under $\mathrm{I}_{125}$ was low in some sections and was high in some sections can be attributed to the fact that the plant can respond similarly to drought stress by having water stress due to over-irrigation as well.

When the stems were histologically and cytologically examined, $\mathrm{I}_{125}$ application increased the thickness of cuticle but it was not significantly affected under $\mathrm{I}_{75}$ application. The thickness of epidermis under $\mathrm{I}_{125}$ was not clearly affected, but under $\mathrm{I}_{75}$ it increased highly significantly. The diameter of xylem vessel increased highly significantly as long as irrigation water reduced. It can be explained that the plant gives a sort of storage reaction by slowing water flow in its stem due to water shortage. In the study including Malatya Kurucaova variety of tomato mentioned in Tuylu et al. (2018), it was determined that, because of water stress in the stem exposed to over-watering and cultivated under hydroponic system, xylem vessels got narrower than those cultivated in perlit condition. Starch and lipid molecules were generally observed in paranchyma cells in the stem under $\mathrm{I}_{100}$ condition. However, starch and lipid molecules were rarely seen in the stem under $\mathrm{I}_{125}$ and $\mathrm{I}_{75}$ conditions. As a result of this observation it can be stated that the stem of the variety examined under water and drought stress can store starch and lipid rarely. According to Sam et al. (2000), structure and functions of all plant organs are affected by water stress. It was observed that electron density in xylems was low in the three conditions. In this case, it can be stated that osmotic balance in the xylem vessels in the stems is normal in the three conditions.

When the leaves were histologically and cytologically examined, the thickness of cuticle under $\mathrm{I}_{125}$ and $\mathrm{I}_{75}$ reduced highly significantly. The thickness of upper epidermis under $\mathrm{I}_{125}$ reduced, but it increased under $\mathrm{I}_{75}$. The thickness of lower epidermis under $\mathrm{I}_{125}$ was not distinctly affected, and it clearly increased under $\mathrm{I}_{75}$. The number of stomate in the upper and the lower epidermis under $\mathrm{I}_{125}$ and $\mathrm{I}_{75}$ conditions was markedly reduced. The average number of stomate in the upper and the lower epidermis responded similarly to over-irrigation and limited irrigation by reducing markedly as stress effect under $\mathrm{I}_{125}$ and $\mathrm{I}_{75}$ conditions. In the study, Makbul et al. (2011) clearly stated that an average number of stomate of upper and lower epidermis in $1 \mathrm{~mm}^{2}$ in soybean increased as a result of drought stress.

The width and length of bullate cell distinctly increased as long as the amount of irrigation water reduced. It means that the plant adapted by increasing its capacity of water storage against drought. The width of mesophyll under $\mathrm{I}_{125}$ condition was 
distinctly increased, but it was slightly increased under $\mathrm{I}_{75}$. The thickness of the midrib region was affected by over-irrigation and got thinner highly significantly under $\mathrm{I}_{75}$ condition. Additionally, while the width of the big vascular bundle under $\mathrm{I}_{125}$ condition increased, it reduced highly significantly under $\mathrm{I}_{75}$ condition. In this case, it can be expressed that the leaf showed the feature of curling developed as an anatomical reaction to stress under $\mathrm{I}_{125}$ condition. In Terzi and Kadıoğlu (2006), it was stated that the response to drought stress is quite related to anatomical and morphological changes such as leaf curling. While the diameter of the xylem vessel under $\mathrm{I}_{125}$ condition narrowed significantly, it narrowed highly significantly under $\mathrm{I}_{75}$ condition. The fact that the distance of the bundles under $\mathrm{I}_{125}$ and $\mathrm{I}_{75}$ conditions increased highly significantly and was pretty much affected by over-irrigation condition was determined. Cytologically, the mesophyll cells were oval or round and regular under $I_{100}$, but they were irregular under $\mathrm{I}_{125}$ and $\mathrm{I}_{75}$. Starch and lipid molecules in the leaves under $\mathrm{I}_{125}$ and I 75 were observed. The vascular bundles and the bundle sheath cells around them under $I_{75}$ were more electron-dense than the ones under $I_{100}$ and $I_{125}$. It can be explained that negative water potential increased in the cells under drought condition. These results conform with Utrillas' and Alegre (1997)'s study carried out in C. dactylon. They stated that mesophyll cells in the leaves under drought stress were more irregular than the ones in well-watered leaves, and starch was observed in mesophyll chloroplasts under stress in C. dactylon.

\section{Conclusion}

In conclusion, in the study of the amount of irrigation water for optimum irrigation, overirrigation and limited irrigation conditions applied were $704 \mathrm{~mm}, 880 \mathrm{~mm}$, and $528 \mathrm{~mm}$, respectively. The changes observed in the root, stem and leaf under over-irrigation and limited irrigation conditions are not anomalies but adaptation attitudes.

According to the results in the study, some features such as length, thickness and diameter in various tissues of the variety of maize examined showed changes due to adaptation to stress conditions. The thickness of cortex and the diameter of xylem vessel in the root, the thickness of cuticle and the diameter of xylem vessel in the stem, the thickness of cuticle, the thickness of upper epidermis, the number of stomate in the upper and the lower epidermis, the length and the width of bullate cell, the width of mesophyll, the diameter of xylem vessel, the distance of bundles, the thickness of midrib region, and the width of big vascular bundle in leaf significantly changed under over-irrigation condition. Under limited irrigation condition, the thickness of cortex and the diameter of xylem vessel in the root, the thickness of epidermis, the diameter of xylem vessel in the stem, the thickness of cuticle, the thickness of the upper and the lower epidermis, the number of stomate in the upper and the lower epidermis, the length and the width of bullate cell, the width of mesophyll, the diameter of xylem vessel, the distance of bundles, the thickness of midrib region, and the width of big vascular bundle in the leaf significantly changed.

As a result, it was figured out that the variety of maize examined developed basic tissues adapting to stress condition and is anatomically suitable for cultivation by over-irrigation and limited irrigation. The ecological condition created by applying $25 \%$ water shortage can be anatomically suggested for the cultivation of maize. This result is significant in terms of saving water in irrigation. In addition, morphological, physiological, etc. parameters of the plant should also be considered for good cultivation and to develop the best method in cultivation. 


\section{REFERENCES}

[1] Abdul Jaleel, C., Manivannan, P., Kishorekumar, A., Sankar, B., Gopi, R., Somasundaram, R., Panneerselvam, R. (2007): Alterations in osmoregulation, antioxidant enzymes and indole alkaloid levels in Catharanthus roseus exposed to water deficit. Colloids and Surfaces B: Biointerfaces 59: 150-157.

[2] Anonymous (2017): Mardin Climate Values (Mardin İklim değerleri). - Turkish State Meteorological Service (Meteoroloji Genel Müdürlüğü), Ankara, Turkey (personally received).

[3] Anonymous (2018): Report about Maize (Misir Raporu). http://www.zmo.org.tr/genel/bizden_detay.php?kod=26263 (accessed 01.01.2018).

[4] Demirok, A. (2017): Searching Applications of Surface and Subsurface Drip Irrigation for Corn (Zea mays L. indendata) Plant in Harran Plain (Harran Ovası'nda Misır (Zea mays L. indendata) Bitkisi için Toprak Üstü ve Toprak Altı Damla Sulama Uygulamalarının Araştırılması). - Harran University Graduate School of Natural and Applied Sciences (Harran Üniversitesi Fen Bilimleri Enstitüsü), Master Thesis (Yüksek Lisans Tezi), Şanlıurfa, Turkey.

[5] Demirok, A., Tuylu, G. İ. (2017): Evaluation of planning and actual irrigation time scheduling for the maize (Zea mays L.) plant in Harran Plain (Harran Ovası'nda Misir Bitkisi (Zea mays L.) için Planlanan ve Gerçekleşen Sulama Zamanı Programının Değerlendirilmesi). - Harran Tarım ve Gida Bilimleri Dergisi 21(1): 84-90.

[6] Korkmaz, H., Durmaz, A. (2017): Responses of plants to abiotic stress factors (Bitkilerin Abiyotik Stres Faktörlerine Verdiği Cevaplar). - GUFBED 7(2): 192-207.

[7] Luft, J. H. (1961): Improvements in epoxy resin embedding methods. - J. Biophys. Biocha. Cytol. 9: 409.

[8] Makbul, S., Saruhan Güler, N., Durmuş, N., Güven, S. (2011). Changes in anatomical and physiological parameters of soybean under drought stress. - Turk J Bot. 35: 369-377. DOI: $10.3906 /$ bot-1002-7.

[9] Metcalfe, C. R. (1960): Anatomy of Monocotyledons. - Clarendon Press, Oxford, pp. 532-536.

[10] Orhangazi, R. (2017): Investigation of Surface and Supsurface Drip Irrigation Applications for Pepper (Capsicum annuum L.) Plant in Harran Plain (Harran Ovası' nda Biber (Capsicum annuum L.) Bitkisi için Toprak Üstü ve Toprak Altı Damla Sulama Uygulamalarının Araştırılması. - Harran University Graduate School of Natural and Applied Sciences (Harran Üniversitesi Fen Bilimleri Enstitüsü), Master Thesis (Yüksek Lisans Tezi), Şanlıurfa, Turkey.

[11] Öktem, A. G., Öktem, A., Özel, M. R. (2017): Methods of Drying and Storing Maize (Misır Tanesini Kurutma ve Depolama Yöntemleri). - 12.Tarla Bitkileri Kongresi Kongre Kitabı, 12-15 Eylül, Kahramanmaraş, pp. 70-73.

[12] Sam, O., Jerez, E., Dell'Amico, J., Ruiz Sanchez, M. C. (2000): Water stress induced changes in anatomy of tomato leaf epidermis. - Biologia Plantarum 43(2): 275-277.

[13] Stempak, J. G., Ward, R. T. (1964): An improved staining method for electron microscopy. - J. Cell Biol. 22: 697.

[14] Terzi, R., Kadıoglu, A. (2006): Drought stress tolerance and the antioxidant enzyme system in Ctenanthe setosa. - Acta Biologica Cracoviensia Series Botanica 48(2): 89-96.

[15] Tuylu, M. (2015): Leaf and Stem Anatomy, Histology, Cytology of Several Marrubum L. (Lamiaceae) Taxons (Bazı Marrubium L. (Lamiaceae) Taksonlarının Yaprak ve Gövde Anatomisi, Histolojisi, Sitolojisi). - University of Süleyman Demirel Institute of Science (Süleyman Demirel Üniversitesi Fen Bilimleri Enstitüsü), Phd. Thesis (Doktora tezi), Isparta, Turkey.

[16] Tuylu, M. (2018): Examination of anatomical features of tomato (Lycopersicon esculentum Mill.) varieties cultivated under hydroponic system. - Applied Ecology and Environmental Research 16(3): 3381-3391. 
[17] Tuylu, M., Tuylu, G. İ., Söylemez, S., Büyükkartal, H. N. (2018): Comparing Some Anatomical Features of Tomato (Lycopersicon esculentum Mill. cv. Kurucaova) Cultivated under Perlit and Hydroponic Culture (Perlit ve Su Kültürü Ortamlarında Yetiştirilen Domates (Lycopersicon esculentum Mill. cv. Kurucaova) Bitkisinin Bazı Anatomik Özelliklerinin Karşılaştırılması) - Süleyman Demirel Üniversitesi Fen Bilimleri Enstitüsü Dergisi. DOI: 10.19113/sdufbed.93255.

[18] Utrillas, M. J., Alegre, L. (1997): Impact of water stress on leaf anatomy and ultrastructure in Cynodon dactylon (L.) Pers. under natural conditions. - International Journal of Plant Sciences 158(3): 313-324. https://about.jstor.org/terms/ (accessed 06.04.2016). 